\title{
Effect of feed supplementation on reproduction, lactation and growth performance of Black Bengal goats grazed on native pasture
}

\author{
NG Saha ${ }^{1 *}$, MR Alam² and MM Rahman ${ }^{3}$
}

${ }^{1}$ Department of Animal Science and Nutrition, Patuakhali Science and Technology University, Babugonj, Barisal, Bangladesh; '2Department of Animal Science, Bangladesh Agricultural University, Mymensingh 2202; ${ }^{3}$ Department of Animal Breeding and Genetics, Bangladesh Agricultural University, Mymensingh 2202, Bangladesh

\begin{abstract}
Effect of feed supplementation to does grazed on naturally grown grasses during pre-partum on growth, reproduction and lactation performances of does and growth of the kids were investigated. Fifteen two-toothed and non-pregnant does of about one and half year of age constituted the experimental animals which were randomly allocated in the three groups of 5 and offered A) grazing ad libitum + $100 \mathrm{~g}$ Mashkalai $+100 \mathrm{~g}$ Wheat bran, B) grazing ad libitum + 50g Mashkalai $+50 \mathrm{~g}$ Wheat bran and C) grazing ad libitum. The dry matter intake (DMI) between supplemented groups of $A$ and $B$ were almost similar ( 90 and $89 \mathrm{~g} / \mathrm{kg} \mathrm{w}^{0.75} / \mathrm{d}$ respectively) and $12 \%$ higher than the control group $C$ $\left(80 \mathrm{~g} / \mathrm{kg} \mathrm{w}^{0.75} / \mathrm{d}\right)$. This DMl represent $4.6,4.5$ and $4.1 \%$ of live weight for group $A, B$ and $C$ respectively. Does in treated group $A$ consumed 30 and $62 \%$ more $C P$ than group $B$ and control group C, respectively. Similarly, group B consumed about $25 \%$ more CP than group C. There was no effect of grazing and supplementation before the pre-partum period on milk yield between treated group ( $A$ and $B$ ) and control group $C(A v .157 \mathrm{ml}$ and $156 \mathrm{ml} / \mathrm{d}$, respectively), rearing rate and growth of the suckling kids. Present study suggests that provision of grazing and supplementary feeding increases nutrients intake of does but appear to have no influence on milk yield. Higher prolificacy of Black Bengal goat may not bring any benefit unless milk production is increased.
\end{abstract}

Key words: Doe, kid, reproduction, lactation, growth, milk yield

Bangladesh Animal Husbandry Association. All rights reserved.

Bang. J. Anim. Sci. 2012. 41 (1): $41-46$

\section{I ntroduction}

A goat is useful to humans when it is living and when it is dead, first as a renewable provider of milk, manure, and fiber, and then as meat and hide. It is the first ruminant livestock that was domesticated around 8000-11000 BC (Tapio et al. 2006). It is believed that goats, as the earliest ruminant to be domesticated (Zeuner 1963) have occupied a place of importance in their long association with man over millennium (Herre and Rohrs, 1973). Among the Asiatic countries, Bangladesh has the second highest population of goats which accounted for about 34.5 million heads (FAO 1997). Goat significantly contributes to the national GDP through the production of $1,30,000$ metric tons (MT) of meat ( $25 \%$ of total meat), $13,12,000$ MT of milk and 3,91,000 MT of skins each year (FAO 2003). Goat population has increased at the rate of $10 \%$ per annum with a simultaneous reduction $(0.21 \%$ per annum) of cattle number from 1970 to 2003 (FAO 1970 and 2003).
In Bangladesh more than $90 \%$ of the goats are of the Black Bengal breed (Husain 1993; Amin et al. 2001), and the remainder being Jamunapari and their crosses (Husain, 1993). The Black Bengal is dwarf goats and is known to be famous for its adaptability, fertility, fecundity, delicious meat and superior skin quality Devendra and Burn 1983; Acharya 1987; Saadullah 1991 and Husain 1993). Due to its small size, goat may significantly play an important role in the economic uplift of the resource-poor farmers. In spite of its importance, very little information is available on the potentials of their productivity in present farming system. In situation of scarce feed resources, an alternative supplementation may enhance them for efficient utilization of natural forage and probably to meet nutritional requirements for various productive purposes. Adequate feed supplementation during the productive stage may help to improve body condition of does and promote growth of the conceptus as well as milk yield. Does with 
higher body weight and fat reserve during late pregnancy and lactation periods may meet their additional energy requirements by mobilizing body reserve for growth of conceptus and sustaining milk synthesis. Higher milk production may help in improving mothering abilities of does for rearing more kids and achieving higher growth and live weight during weaning which may reduce age and increase live weight for marketing and improve life time performance. Considering the above facts and circumstances, the present experiment was designed to investigate the effect of different supplements in grass based diet on reproduction, growth and lactation performance of Black Bengal does and growth of the kids.

\section{Materials and Methods}

Fifteen non-pregnant two-toothed does were randomly divided equally into 3 groups of 5 with a mean live weight of $15 \pm 0.21 \mathrm{~kg}$ for group $A$, $B$ and $C$ respectively. Feeding trials were conducted at 6 weeks before the mating and parturition, and during the trials all the does were freely grazed in the field and in addition to grazing, does belong to group $A$ and $B$ were offered $100 \mathrm{~g}$ Mashkalai $+100 \mathrm{~g}$ Wheat bran, and $50 \mathrm{~g}$ Mashkalai $+50 \mathrm{~g}$ Wheat bran, respectively while group $C$ remained as control. Feed supplementation was offered to the goats aimed at providing crude protein of on an average of $80 \mathrm{~g}$ to group $A$ as recommended by NRC (1981) for goats, and B was offered half of the recommended protein supplement. During the flushing period, does were dosed with $1 \mathrm{~g}$ of chromic oxide per day for 10 days and at 7th day grab faecal samples were collected from the does for 3 subsequent days for determination of intake of grasses in grazing condition. Intake of supplements was recorded daily and during the chromic oxide dosing, samples of grasses and supplements were collected for determination of nutrient contents. After the flushing periods, does of different groups remained on grasses only. Live weight changes were measured on weekly basis and were continued throughout the experiment. Birth weight of the kids was recorded soon after parturition. Kids were allowed to suckle their mothers and their growth rate was recorded every week. On every third day of the suckling period, kids were separated from their mothers for $24 \mathrm{hrs}$, and during this time, does were milked by hand for estimation of milk yield. This process was continued till the cessation of potential milk secretion. All the data were analyzed by statistical method using analysis of variance (Steel and Torrie 1980) for completely randomized design (CRD) and mean values were tested for difference with least significant difference (LSD).

\section{Results and Discussion}

\section{Nutrients intake}

The amounts of nutrient intake of does grazed grasses along with supplement are presented in Table 1 . Table 1 shows that there were no significant differences in the dry matter intake (DMI) among the different groups of animals. The DMI between supplemented groups of $A$ and B were almost similar but 13 and $11 \%$ higher respectively than the control group C. This DMI represent $4.6,4.5$ and $4.1 \%$ of live weight for group A, B and C, respectively. During pre-mating period the supplemented group consumed $(86 \mathrm{~g} / \mathrm{d})$ relatively more DM than the control group $(69 \mathrm{~g} / \mathrm{d})$. It appeared that all the does in different groups might probably achieve maximum intake which were almost in conformity with the values of 4 to $5 \%$ reported by Devendra and Mcleory (1982). The higher intake of DM in each group during later part of pre-partum period was probably due to higher energy demand for foetal growth and higher requirements for body maintenance and growth of does. There were significant differences $(p<0.01)$ in crude protein intake (CPI) among the different groups. Does in treated group A consumed 30 and $62 \%$ more CP than group B and control group C, respectively. Similarly group $B$ consumed about $25 \%$ more CP than group C. This higher intake of $\mathrm{CP}$ was probably due to higher supply of dietary protein to the does in treated group ( $A$ and $B$ ) than in control group $C$. Organic matter and neutral detergent fibre intake did not differ significantly among the different groups. Almost similar consumption of OM and NDF was observed within the treated groups but this consumption was 16 and $13 \%$ higher for $O M$, and 10 and $8 \%$ higher for NDF in group A and B than group $\mathrm{C}$, respectively.

\section{Live weight changes of does}

The average daily gains of does were 66,53 and $32 \mathrm{~g}$ for group $\mathrm{A}, \mathrm{B}$ and $\mathrm{C}$, respectively. It appeared from Table 2 that flushing has 


\section{Feed supplementation on goats performance}

significant effect on pre-partum period. During the flushing period, does belong to treated group ( $A$ and $B$ ) were observed to put on more weight and increased live weight (Av. 60g/d) i.e., $53 \%$ higher than the group $C(32 \mathrm{~g} / \mathrm{d})$. The trend of growth is shown in Figure 1 . This gain was higher up to 4th week in the supplemented groups whereas goats given no supplements did not show improvement of growth rate, although this weight gain in group $\mathrm{C}$ was even higher than the does observed in village condition (Alam and Islam, 199I). Alam et al. (1992) have observed similar live weight gain by flushing of does before the mating period. In farming situation, body condition of grazing goats is considerably improved by supplementation of concentrates (Branca and Casu 1987). The present trial further validated the finding that improved diet during pre-partum improved body condition. This may have beneficial effect in subsequent pregnancy and lactation periods.

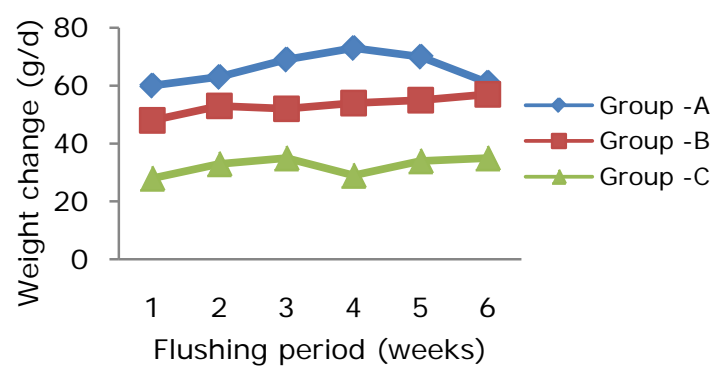

Figure 1. Growth trend of does due to flushing

\section{Gestation length and litter size}

Table 2 revealed that supplementation of feed had no significant effect on gestation length and litter size. The average gestation length and litter size in the present study was found to be 147 days and 1.2 , respectively.

\section{Birth weight of kids}

Supplementation had no significant effect on birth weight of kids (Table 2). The average birth weight of kids for A, B and C group were 0.97, 1.18 and $1.37 \mathrm{~kg}$, respectively which was similar to the values of 1.3 and $1.1 \mathrm{~kg}$ for single male and female, respectively, observed by Guha et al. (1968) in Black Bengal goats. It was found that litter size had a positive influence on birth weight of kids and low litter size contributed to this weight of kid in control group than that of supplemented groups ( $A$ and $B$ ).

\section{Lactation performance}

The effect of feed supplement on lactation performance of does is shown in Table 3. Total milk yield for group A, B and C were 10.2, 10.9 and 10.6 liters in a lactation period of 69,66 and 68 days, respectively. There was no significant difference in milk yield and lactation length and effect of feeding appeared to have no influence on does in different groups. All the does reached to peak milk yield at about 4 weeks of lactation period and the yield declined thereafter. The average milk yield of 10.5 liters was observed for an average lactation length of 68 days in this study. This was probably due to the genetic and environmental factors as well as the does in first lactation produced less milk than their subsequent lactation (Edey 1983).

Among the does which gave birth to twin kids produced more milk than the does with single kids. Similar result was also obtained by Rai and Chorey (1965), and Sacker and Trail (1966). They found that goat responds to multiple suckling by increasing their milk yield and this response depends on the number of kids suckled.

Table 1. Nutrient intake of does grazed on grasses along with supplement ( $\pm S E)$

\begin{tabular}{lccc}
\hline Feeding group* & A & B & C \\
\hline DM Intake $\left(\mathrm{g} / \mathrm{kgW}^{0.75} / \mathrm{d}\right)$ & $89.80 \pm 6.64$ & $89.00 \pm 2.93$ & $80.20 \pm 4.93$ \\
DMI (\% of live weight) & $4.60 \pm 0.33$ & $4.50 \pm 0.15$ & $4.10 \pm 0.25$ \\
OM intake $\left(\mathrm{g} / \mathrm{kgW}^{0.75} / \mathrm{d}\right)$ & $80.20 \pm 5.81$ & $78.40 \pm 2.86$ & $69.00 \pm 4.23$ \\
$\mathrm{CP}$ intake $\left(\mathrm{g} / \mathrm{kgW}^{0.75} / \mathrm{d}\right)$ & $12.80 \pm 0.84$ & $9.90 \pm 0.45$ & $8.10 \pm 0.55$ \\
Mean CPI $(\mathrm{g} / \mathrm{d})$ & $99.20^{\mathrm{a}} \pm 7.31$ & $75.70^{\mathrm{b}} \pm 2.44$ & $61.10^{\mathrm{c}} \pm 3.78$ \\
NDF intake $\left(\mathrm{g} / \mathrm{kgW}^{0.75} / \mathrm{d}\right)$ & $54.20 \pm 3.57$ & $53.00 \pm 1.79$ & $48.80 \pm 3.03$ \\
\hline
\end{tabular}

${ }^{*} \mathrm{~A}$, grazed ad libitum+100g mashkalai+100g wheat bran; B, grazed ad libitum+50g mashkalai+50g wheat bran; $C$, grazing ad libitum; Means with different superscripts in the same row differed significantly $(p<0.01)$ 
Saha et al. (2012) Bang. J. Anim. Sci. 41 (1): 41-46

Table 2. Effect of flushing of does on live weight, gestation length, litter size and birth weight of kids

\begin{tabular}{lllll}
\hline \multirow{2}{*}{ Parameter } & \multicolumn{3}{l}{ Feeding group } \\
\cline { 2 - 5 } & & $\mathrm{A}$ & $\mathrm{B}$ & $\mathrm{C}$ \\
\hline Live weight gain of does $(\mathrm{g} / \mathrm{d})$ & & $66.00^{\mathrm{a}} \pm 2.62$ & $53.17^{\mathrm{b}} \pm 1.65$ & $32.33^{\mathrm{c}} \pm 1.39$ \\
Gestation length (days) & & $145.80 \pm 1.60$ & $147.40 \pm 1.52$ & $148.00 \pm 1.25$ \\
Average litter size & 1.8 & 1.4 & 1.2 \\
\hline \multirow{2}{*}{ Birth weight of kids $(\mathrm{kg})$} & Single & $1.08 \pm 0.09$ & $1.35 \pm 0.13$ & $1.53 \pm 0.09$ \\
& Twin & $0.82 \pm 0.11$ & $0.92 \pm 0.06$ & $0.89 \pm 0.01$ \\
& Average & $0.97 \pm 0.09$ & $1.18 \pm 0.14$ & $1.37 \pm 0.01$ \\
\hline
\end{tabular}

SE, standard error; means with different superscripts in the same row differed significantly $(p<0.01)$

Table 3. Effect of flushing on milk yield of does and growth of kids

\begin{tabular}{|c|c|c|c|c|c|c|c|c|c|}
\hline \multirow{3}{*}{$\begin{array}{l}\text { Parameter } \\
\text { Birth type }\end{array}$} & \multicolumn{9}{|c|}{ Feeding group } \\
\hline & \multicolumn{3}{|c|}{$A$} & \multicolumn{3}{|c|}{$\mathrm{B}$} & \multicolumn{3}{|c|}{$\mathrm{C}$} \\
\hline & Single & Twin & Mean & Single & Twin & Mean & Single & Twin & Mean \\
\hline Milk yield & 141.80 & 153.40 & 147.60 & 150.33 & 179.00 & 164.67 & 135.33 & 176.67 & 156.00 \\
\hline$(\mathrm{ml} / \mathrm{d})$ & \pm 4.82 & \pm 3.84 & \pm 9.00 & \pm 9.01 & \pm 28.36 & \pm 24.75 & \pm 3.32 & \pm 9.87 & \pm 7.09 \\
\hline Growth rate & 33.35 & 29.14 & 31.25 & 38.07 & 28.29 & 33.18 & 41.14 & 27.21 & 34.18 \\
\hline$(g / d)$ & \pm 1.88 & \pm 0.6 & \pm 3.48 & \pm 16.69 & \pm 2.12 & \pm 13.39 & \pm 1.86 & \pm 8.60 & \pm 6.22 \\
\hline
\end{tabular}

SE, standard error

The body condition of suckling goats becomes lower due to larger milk excretion than that of milking goats (Santucci 1985). In this experiment, does having twin kids produced $31 \%$ more milk than does having single kid which was comparable to the value of $24 \%$ reported by Beischer et al. (1992) for Australian Feral goats. This could have an effect of number of sucklers than body condition of does. It appeared that the milk yield and lactation length of Black Bengal does were lower than other breeds of goat found in literature. This may have reduced the ability of does to rear more kids. Higher prolificacy of this breed may not bring any benefit on reproductive performance.

\section{Growth of the kids}

Effect of flushing on milk yield by does and growth rate of the kids of different birth type are shown in Table 3. There was no significant effect of flushing on overall growth rate of the kids of different groups of does as well as growth rate among the single and twin born kids. Average growth rate of single born kid was about $32 \%$ higher than that of twin born. The value was greater than the value of $23 \%$ reported by Pralomkarn et al. (1991) in Thai native does. This was probably due to higher birth weight of single born kid and the milk produced by does was sufficient to rear single kid. Zygoyiannis and Katsaounis (1986) reported that the twin born kids and female kids have lower growth rates from birth to weaning than do single which was similar to present findings.

In this study, growth of the sucklers during the pre-weaning period greatly influenced by milk yield of their mother. Does with multiple birth were unable to meet the demands of milk for offspring. Consequently, their growth rates fell behind those of singles during the suckling periods. Banda et al. (1992) reported that for maximum growth of a kid of $2.1 \mathrm{~kg}$ birth weight requires $1,137 \mathrm{KJ}$ milk energy $/ \mathrm{kg} \mathrm{W}^{0.75} /$ day over the first 4 weeks of lactation. This would be supplied by 1.2 liters of milk daily. But the Black Bengal does produce insufficient milk (Average $155 \mathrm{ml} / \mathrm{d}$ ) and appeared to be low for the requirement of a kid for sustaining their growth. It appeared that provision of feed supplementation to grazing does before prepartum increased basal feed intake which in turn helps to meet the higher energy and protein requirements during the late pregnancy and increased live weight of does. 


\section{Feed supplementation on goats performance}

Flushing had no effect on milk yield and the does produced sufficient milk only for nourishing one kid. The single born kid promoted higher live weight gain than the twinborn kid but their rate of improvement was very low. Availability of sufficient milk during the pre-weaning period would ensure higher growth of kids and higher prolificacy of Black Bengal goat may have been benefited by farmers. Further investigations are required to study the factors affecting milk production of Black Bengal goats. Selection and improved feeding of does having higher milk producing ability may improve milk supply for exploitation of growth of kids and rearing rate of does.

\section{Conclusion}

It is concluded that feed supplementation to grazing does before the pre-partum increases nutrients intake as well as live weight gain and body tissue reserves in does which may help for exploitation of potential productivity of does in subsequent reproductive performance. Milk yield of Black Bengal does was very low and this may have reduced the ability to rear more kids. Higher prolificacy of this breed may not bring any benefit unless milk production is increased.

\section{Acknowledgement}

The authors gratefully acknowledges the International Atomic Energy Agency, Vienna for financial help under the research project no. 4912/RB for this research work.

\section{References}

Acharya RM (1987). Breeds of goats and research programmes for their improvement in India. Proc. IV Int. Conf. on goats. Vol. 1, Brazil.

Alam MR (1992). Studies on feeding systems for the development of production strategies for goats in Bangladesh. In: feeding strategies for improving ruminant productivity in areas of fluctuating nutrient supply. International Atomic Energy Agency, Vienna IAEA -TECDOC - 691, P. 135-143.

Alam MR and Islam M (1991). Effects of deworming and supplements on growth performance of goats. Proc. Bang. Agric. Univ. Res. Pro. 5: 388-393.
Alam MR, Saha NG and Sarker N (1992). Effect of supplementation on reproductive and lactational performances of does and growth of sucklers. Proc. Bang. Agric. Univ. Res. Pro. 6: 383-389.

Amin MR, Husain SS and Islam ABMM (2001). Reproductive peculiarities and litter weight in different genetic groups of Black Bengal does. Asian-Aust. J. Anim. Sci. 14: 297301.

Banda JW, Steinbach J and Zerfas HP (1992). Milk yield, milk composition and kid growth in Boer and East African goats in Malawi. In: Recent Advances in Goat Production. R. R. Lokoshwar (Ed). pp. 505-510

Beischer AA, Pattie WA, and Norton BW (1992). Environmental factors influencing the growth of Australian feral goats. Small Rumin. Res. 5: 98-101.

Branca A and Casu S (1987). Variation of body condition score during a year and its relationship with body reserves in Sarda goats. In: L'evaluation des ovins caprins Medit. Symposium, Flamant, J.C. and Morand-Fahr, P (Eds). pp. 221-236.

Devendra C and Mcleory GB (1982). Sheep and Goat Production in the Tropics. Intermediate Tropical Agriculture series. Longman Group Limited, Essex, U.K.

Devendra C and Burn M (1983). Goat Production in the Tropics. Commonwealth Agricultural Bureaux, U.K.

Edey TN (1983). Lactation, growth and body composition. In: A course Manual in Tropical Sheep and Goat Production.

Edey TN (Ed). Australian Universities International Development Program, Canberra, P. 83-96.

FAO (1970). FAO Production Year Book, 1970. Food and Agricultural Organization of the United Nations. Rome, I taly.

FAO (1997). FAO Production Year Book, 1994. Food and Agricultural Organization of the United Nations. Rome, Italy. Vol. 51.

FAO (2003). FAO Production Year Book, 2003. Food and Agricultural Organization of the United Nations. Rome, I taly.

Guha H, Gupta S, Mukherjee AK, Moulick SK and Bhattacharya S (1968). Some causes of variations in the growth rates of Black Bengal goats. Indian J. Vet. Sci. and Anim. Husb. 38: 269-278.

Herre W and Rohrs M (1973). Introduction of Domestic Animals (Zoological Aspects). 
Stuttgart, German Federal Republic by B. Fisher.

Husain SS (1993). A study on the productive performance and genetic potentials of Black Bengal goats. Ph.D. Thesis, Department of Animal Breeding and Genetics, Bang. Agril. Univ., Mymensingh.

NRC (1981). National Research Council. Nutrient Requirement for goats. No. 15 National Academy Science, Washington D.C.

Pralomkarn W, Saithanoo S, Milton JTB, Praditrungwatana $\mathrm{L}$ and Kochapakdee $\mathrm{S}$ (1991). The pre-weaning growth of Thai native kids. Proc. Int. Sem. held in Hat Yai, Thailand, 28-31 May, P. 164-169.

Rai GS and Chorey PA (1965). Lactational performanoe of Jamnapari and Barbari goats. Indian Vet. J. 42: 958-961.

Saadullah M (1991). Research and development activities and needs on small ruminant in Bangladesh. Paper presented at SRUPNA $1^{\text {st }}$ Annual Workshop, July 1991, Bogra, Indonesia.
Sacker GD and Trail JCM (1966). Production characteristics of a herd of East African Mubende goats. Trop. Agric. of Trinidad, 43: 43-51.

Santucci P (1985). Goat farming in extensive conditions indicators for herd management. 36th IAAP Annual Meeting, Sept.30-Oct.3, 1985, Greece.

Steel RGD and Torrie JH (1980). Principles and Procedures of Statistics: A Biometrical Approach, 2nd Ed. McGrew-Hill Book Company, New York.

Tapio M, Marzanov N, Ozerov M, Gonzarenko G, Kiselyova $\mathrm{T}$, Murawski $\mathrm{M}$, Viinalass $\mathrm{H}$ and Kantanen J (2006). Sheep mitochondrial DNA variation in European Caucasian and Central Asian areas. Mol. Bio. Evo. 23: 1176-1783.

Zeuner FE (1963). History of Domestic Animals. London, U.K. Hutchingson and Co. (Publishers) Ltd. 560 (ABC, 31: 2041).

Zygoyiannis D and Katsaounis N (1986). Milk yield and milk composition of indigenous goats (Capra prisca) in Greece. Anim. Prod. 42: 365-374. 